\title{
Kontrol Diri terhadap Perilaku Cybersex pada Remaja
}

\author{
Ummu Hani $^{1}$, Rini Hartati ${ }^{2}$, Nurul Aiyuda ${ }^{3}$ \\ Fakultas Psikologi Universitas Abdurrab \\ Kampus 3, Jalan Pattimura No 1 Cinta Raja Sail ${ }^{123}$ \\ ummukhazain@gmail.com ${ }^{1}$
}

\begin{abstract}
Abstrak
Penelitian ini bertujuan untuk mengetahui hubungan kontrol diri dengan perilaku cybersex pada remaja di Pekanbaru. Penelitian dilakukan di kota Pekanbaru dengan jumlah subjek 211 remaja (107 laki-laki ; 104 perempuan). Penelitian ini adalah jenis penelitian kuantitatif dengan teknik pengambilan sampel menggunakan sampling kuota. Instrumen pengumpulan data yang digunakan dalam penelitian ini skala kontrol diri dengan reliabilitas $\alpha$ 0,688 dan perilaku cybersex dengan $\alpha$ 0,718. Analisis data menggunakan korelasi non-parametrik Spearman's Rho dengan nilai signifikan $-0,292 * *(\mathrm{p}<0,01)$. Hal ini menunjukkan hipotesis diterima dengan adanya hubungan negatif antara kontrol diri dengan perilaku cybersex pada remaja di Pekanbaru. Semakin tinggi kontrol maka, semakin rendah perilaku cybersex pada remaja Pekanbaru. Sebaliknya semakin rendah kontrol diri maka semakin tinggi perilaku cybersex remaja di Pekanbaru. Pada penelitian ini laki-laki memiliki perilaku cybersex lebih tinggi dibanding perempuan yang dapat menjadi masukan bagi penelitian selanjutnya.
\end{abstract}

Kata kunci : kontrol diri, cybersex, online

\begin{abstract}
This study aims to determine the relationship of self-control with cybersex behavior in adolescents in Pekanbaru. The study was conducted in the city of Pekanbaru with a total of 211 teenage subjects (107 males; 104 females). This research was a type of quantitative research with sampling techniques using quota sampling. Data collection instruments used in this study self-control scale with a reliability of $\alpha 0.688$ and cybersex behavior with $\alpha 0.718$. Data analysis used non-parametric Spearman's Rho correlation with a significance value of $-0.292 * *(p<0.01)$. This shows the hypothesis is accepted by the negative relationship between self-control and cybersex behavior in adolescents in Pekanbaru. The higher the control, the lower the cybersex behavior in adolescents in Pekanbaru. Conversely the lower the self-control, the higher the cybersex behavior of adolescents in Pekanbaru. In this study, males have higher cybersex behavior than a female who can be suggested for future research.
\end{abstract}

Keywords: Self Control, Cybersex Behavior, Online

\section{PENDAHULUAN}

Berdasarkan hasil survei Asosiasi Penyelenggara Jasa Internet Indonesia atau di singkat APJII terjadi peningkatan pengguna internet di Indonesia sejak tahun 2017 ke 2018. Tahun 2017 jumlah penetrasi pengguna internet adalah 143,26 juta jiwa dari seluruh total populasi penduduk Indonesia (APJII, 2018), sementara di tahun 2018 penetrasi pengguna internet berjumlah 171,17 dari total 264,16 penduduk Indonesia (APJII, 2019). Penetrasi pengguna internet di Indonesia berdasarkan usia terbanyak adalah antara usia 15-19 tahun, sebesar $91 \%$ (APJII , 2018a) hasil ini menunjukan bahwa pengguna internet mayoritas adalah usia remaja. Sementara hasil survei yang dilakukan Komisi Perlindungan Anak Indonesia (KPAI) pada tahun 2014 menunjukkan bahwa persentase individu terpapar konten pornografi di Internet memprihatinkan. tercatan 784 kasus yang dilaporkan dengan 90\% telah terpapar sejak usia 11 tahun (KPAI, 2014). 
Penggunaan internet untuk pencarian informasi seks merupakan aktifitas yang bisa dilakukan, mengingat salah satu tugas perkembangan masa remaja adalah mampu menerima dan memahami peran seks usia dewasa (Hurlock, 2014). Namun demikian, hal tersebut bisa berdampak negatif bila informasi yang di dapatkan terkait perilaku seks tidak di terima dan disampaikan dengan benar (Utari, Syarifah, \& Lubis, 2012). Agustina dan Hafiza (2013) mengatakan bahwa individu di usia remaja cendrung menggunakan internet untuk tujuan cybersex lebih banyak di banding pada usia lain. Kemudian hasil penelitian Cooper, Daneback, dan Mansson (2005) menyebutkan usia paling banya melakuakan cybersex adalah usia 18 sampai 24 tahun.

Penelitian mengungkapkan bahwa pornografi dapat menurunkan fungsi kognitif dan memori verbal (Prawiroharjo et al., 2019). Lebih jauh, pornografi dapat memberikan dampak biologs maupun sisi psikologis yang tergambar dari perliaku individu, dijelaskan oleh Cooper, Delmonico, dan Burg (2000) bahwa individu yang menonton tayangan pornografi di internet secara berkelanjutan dan terus menerus termasuk ke dalam kriteria permasalahan seksual kompulsif. Penelitian oleh Rahman dan Permadi (2013) menunjukkan bahwa individu yang mengidentifikasi nilai-nilai akan menyebabkan individu lebih mudah untuk menghindar dari perilaku cybersex. Selain berbahaya untuk kinerja otak, perilaku cybersex dianggap sebagai hal yang bertentangan dengan nilai-nilai agama. Hal ini seperti yang tercantum secara eksplisit pada Al-Quran Surat Al Israa' ayat 32 :

"Dan janganlah kamu mendekati zina, sesungguhnya zina itu adalah suatu perbuatan yang keji. Dan suatu jalan yang buruk”.

Hasil penelitian yang dilakukan oleh Jay Phelan, seorang professor biologi di Universitas California Los Angeles (UCLA) menyatakan bahwa masalah pornografi dan seksualitas yang terkait dengan internet merupakan salah satu permasalahan kontrol diri (Phelan \& Burnham, 2000). Kontrol diri merupakan kemampuan individu dalam mengamati situasi diri dan lingkungan yang ditunjukkan dengan cara individu untuk menampilkan diri dalam melakukan sosialisasi, berupa kemampuan pengendalian perilaku, kecenderungan menarik perhatian, keinginan mengubah perilaku untuk sesuai dengan pendapat orang lain, atau bahkan menyembunyikan perasaan (Ghufron \& Risnawita, 2012). Individu yang mampu mengembangkan kontrol diri akan mampu menahan diri untuk tidak dan menghindari perilaku yang berlawanan dengan norma-norma sosial (Tangney, Baumeister, \& Boone, 2004). Ghufron dan Risnawita (2012) menyatakan bahwa semakin bertambahnya usia seseorang, maka semakin baik kemampuan mengontrol dirinya. Pada usianya remaja di harapkan sudah mampu mengontrol diri dalam berperilaku, namun disisi lain menurut Anggreiny dan Sarry (2018) remaja cukup berisiko untuk melakukan cybersex. Sedangkan penelitian (Lestari \& Hartosujono, 2017) mengungkapkan bahwa kontrol diri yang baik pada individu membuat remaja semakin mampu mengendalikan perilaku cybersex.

Berdasarkan uraian di atas, perilaku cybersex saat ini telah mengalami peningkatan beriringan dengan meningkatnya jumlah pengguna internet, terutama di kota-kota besar, bahkan Sumatra merupakan wilayah kedua pertumbuhan penetrasi internet terbesar setelah pulau Jawa (APJII, 2018a). Tingginya cybersex ini menurut beberapa temuan sebelumnya dapat di kendalikan oleh peningkatan kontrol diri di kalangan remaja sehingga penelitian ini ditujukan untuk mengetahui hubungan kontrol diri dengan perilaku cybersex pada remaja. 


\section{METODE}

Penelitian ini menggunakan metode kuantitatif dengan pendekatan korelasional. Subjek dalam penelitian ini adalah remaja di Pekanbaru yang telah mengakses cybersex dengan rentang usia 12 sampai 22 tahun. Subjek terdiri dari 107 laki-laki dan 104 perempuan. Teknik pengambilan sampel yang digunakan dalam penelitian ini adalah non probability sampling dengan bentuk sampling kuota. Alat ukur yang digunakan dalam penelitian ini menggunakan skala perilaku cybersex dan kontrol diri.

Skala perilaku cybersex dalam penelitian ini disusun berdasarkan aspek-aspek perilaku cybersex menurut Delmonico dan Miller (2003) yaitu: online sexual compulsivity, online sexual behaviour-social, online sexual behaviour-isolated, online sexual spending dan interest in online sexual behavior. Skala ini terdiri dari 29 item pernyataan. Skala kontrol diri dalam penelitian ini disusun oleh peneliti berdasarkan aspek-aspek kontrol diri menurut Tangney, Baumeister, dan Boone (2004) yaitu: disiplin diri (self-dicipline), tindakan atau aksi yang tidak impulsif (deliberate atau non-impulsive), kebiasaan baik (healthy habits), etika kerja (work etic) dan keterandalan atau keajegan (reliability). Skala ini terdiri dari 35 item pernyataan. Skala ini dibuat dalam lima alternatif jawaban menurut Azwar (2018) yaitu, Hampir Tidak Pernah (HTP), Sangat Jarang (SJ), Kadang-Kadang (KD), Sangat Sering (SS), dan Hampir Selalu (HSL). Hasil uji reliabilitas alpha cronbach skala perilaku cybersex dengan hasil sebesar 0,718, sedangkan koefisien reliabilitas alpha cronbach skala kontrol diri sebesar 0,688.

HASIL

Tabel 1.

Deskripsi demografi subjek penelitian

\begin{tabular}{ccc}
\hline Jenis Kelamin & Frekuensi & \% \\
\hline Laki-laki & 107 & 50,7 \\
\hline Perempuan & 104 & 49,3 \\
\hline Usia & Frekuensi & $\mathbf{\%}$ \\
\hline $12-15$ tahun (remaja awal) & 11 orang & 5,21 \\
\hline $16-18$ tahun (remaja tengah) & 74 orang & 35,07 \\
\hline $19-22$ tahun (remaja akhir) & 126 orang & 59,71 \\
\hline
\end{tabular}

Berdasarkan deskripsi data yang didapat dalam penelitian ini, peneliti melakukan pengkategorisasian antara kedua variabel, yaitu kategorisasi perilaku cybersex, dan kategorisasi kontrol diri. Hasil pengkategorisasian dapat dilihat pada tabel 2. di bawah ini:

Tabel 2.

Kategori variabel Penelitian

\begin{tabular}{ccccccc}
\hline \multirow{2}{*}{ Variabel } & \multicolumn{2}{c}{ Tinggi } & \multicolumn{2}{c}{ Sedang } & \multicolumn{2}{c}{ Rendah } \\
\cline { 2 - 7 } Cybersex & Frekuensi & $\%$ & Frekuensi & $\%$ & frekuensi & $\%$ \\
\hline Kontrol diri & 5 & $2 \%$ & 61 & $29 \%$ & 146 & $69 \%$ \\
\hline
\end{tabular}


Berdasarkan kategori perilaku cybersex pada tabel 2. Hasil perhitungan menunjukkan dari 211 sampel penelitian terdapat $69 \%$ cybersex pada kategori rendah, $29 \%$ cybersex pada kategori sedang, dan $2 \%$ pada kategori tinggi. Pada variabel kontrol diri hasil perhitungan menunjukkan dari 211 sampel penelitian, 73,5\% kontrol diri pada kategori sedang dan untuk kategori tinggi sebesar $26,5 \%$.

\section{Uji Asumsi}

Berdasarkan hasil uji normalitas kolmogorov smirnov variabel perilaku cybersex dan kontrol diri pada remaja di Pekanbaru diperoleh, nilai $p$ sebesar 0,200 (p>0,05) untuk cybersex, dan $p$ sebesar 0,000 ( $<<0,05)$ untuk kontrol diri. Dengan demikian dapat disimpulkan bahwa sebaran data variabel perilaku cybersex normal dan kontrol diri memiliki sebaran data yang tidak normal. Berdasarkan hasil uji linearitas diperoleh $\mathrm{F}=1,813$ dan $p=0,000(<0,05)$. Signifikansi kurang dari 0,05 , maka dapat disimpulkan bahwa antara variabel kontrol diri dengan variabel perilaku cybersex terdapat hubungan yang linier.

\section{Uji Hipotesis}

Tabel 3.

Hasil Uji Korelasi Spearman's Rho

\begin{tabular}{cccc}
\hline Variabel & Sig & Korelasi & Keterangan \\
\hline Kontrol diri terhadap perilaku cybersex. & $<0,01$ & $-0.292^{* *}$ & signifikan \\
\hline
\end{tabular}

Berdasarkan hasil uji korelasi spearman's rho pada tabel 3, didapatkan hasil $(\mathrm{r})=-0.292^{* *}$ $(\mathrm{p}<0,01)$ yang artinya tingkat kekuatan hubungan (korelasi) antara variabel kontrol diri dengan perilaku cybersex adalah sebesar -0.292 (hubungan rendah). Tanda bintang (**) artinya korelasi bernilai signifikan pada angka signifikansi sebesar 0,01. Angka koefisien korelasi pada tabel di atas bernilai (negatif) yaitu -0.292 , sehingga terdapat hubungan negatif antara kontrol diri dengan perilaku cybersex pada remaja di Pekanbaru dan hal ini menunjukkan bahwa hipotesis diterima.

Tabel 4.

Hasil Uji Beda Mann-Whitney Test

\begin{tabular}{cccccc}
\hline & & N & Mean & Sig. (2-tailed) & Keterangan \\
\hline \multirow{2}{*}{ Perilaku Cybersex } & Laki-Laki & 107 & 124.36 & \multirow{2}{*}{0,000} & \multirow{2}{*}{ Ada perbedaan } \\
& Perempuan & 104 & 87.11 & & \\
\hline
\end{tabular}

Dari hasil uji beda di atas menunjukkan nilai Sig. (2-tailed) sebesar 0,000 ( $\mathrm{p} \leq 0,05)$, maka dapat dikatakan bahwa ada perbedaan perilaku cybersex antara laki-laki dan perempuan. Hasil uji statistik diperoleh mean $=124,36$ untuk laki-laki sedangkan mean $=87,11$ untuk perempuan, hasil berdasarkan mean ini mengungkapkan bahwa laki-laki memiliki perilaku cybersex lebih tinggi dari pada perempuan. 


\section{PEMBAHASAN}

Penelitian ini bertujuan untuk melihat hubungan antara kontrol diri terhadap perilaku cybersex pada remaja di Pekanbaru. Berdasarkan hasil perhitungan uji hipotesis didapatkan angka koefisien korelasi bernilai negatif. Tingginya kontrol diri, maka menyebabkan rendahnya perilaku cybersex, sebaliknya individu dengan kontrol diri rendah, menyebabkan semakin tinggi perilaku cybersex pada remaja.

Hasil penelitian ini didukung oleh beberapa penelitian yang menunjukkan terdapat hubungan antara kontrol diri dengan cybersex (Dewangga \& Rahayu, 2015; Lestari \& Hartosujono, 2017). Lestari dan Hartosujono (2014) menunjukkan adanya hubungan yang signifikan antara kontrol diri dengan perilaku cybersex remaja. Intervensi tentang pengendalian cybersex cenderung berusaha membuat individu untuk memiliki kotnrol atas perilaku bermasalah, namun disisi lain individu yang berusaha mengendalikan diri atas perilaku bermasalah seperti cybersex juga di sebutkan justru memilki perilaku kecanduan. (Cooper et al., 2000). Individu yang memiliki perilaku cybersex yang lebih tinggi memiliki waktu online lebih banyak dibanding yang tidak terlibat dalam cybersex (Daneback, Cooper, \& Månsson, 2005), hal ini juga senada dengan penelitian Dewangga dan Rahayu (2015) menambahkan bahwa kontrol diri diperlukan untuk mengendalikan perilaku adiksi cybersexual.

Pada umumnya remaja cenderung berisiko dalam menolak aturan meskipun mendapatkan teguran dari orang dewasa seperti orang tua ataupun guru, bahkan remaja juga dapat dikatakan berisiko terpapar pornografi di internet (Anggreiny \& Sarry, 2018). Ditambah lagi internet memberikan kesempatan untuk remaja mengekplorasi konten pornografi (Ballester-Arnal, Giménez-García, Gil-Llario, \& Castro-Calvo, 2016). Penelitian Daneback dkk., (2005) memberikan gambaran tentang pengalaman cybersex pada usia 18-65 tahun, hasilnya menunjukkan bahwa rata-rata pengalaman cybersex tertinggi berada pada pada usia 18-24 tahun. Lebih lanjut penelitian Daneback dkk., (2005) menunjukkan bahwa pengalaman cybersex laki-laki pada usia remaja (18-24 tahun) memiliki persentase lebih tinggi dibanding remaja perempuan.

Penelitian ini juga menunjukkan temuan yang sama dengan temuan sebelumnya bahwa terdapat perbedaan perilaku cybersex antara laki-laki dan perempuan. Laki-laki memiliki perilaku cybersex lebih tinggi dibanding perempuan. Hal tersebut sesuai dengan yang diungkapkan oleh Weinstein, Zolek, Babkin, Cohen, dan Lejoyeux (2015) bahwa pria memiliki frekuensi penggunaan cybersex yang lebih tinggi dari pada wanita. Penelitian Ballester-Arnal dkk. (2016) mendukung bukti penelitian sebelumnya secara umum, remaja laki-laki lebih banyak melakukan perilaku cybersex dari pada perempuan. Namun demikian temuan ini inkonsisten dengan temuan penelitian yang menyatakan bahwa remaja dengan adiksi pornografi memiliki dampak penurunan memori verbal tanpa memandang jenis kelamin, dengan kata lain laki-laki dan perempuan tidak memiliki perbedaan dalam adiksi pornografi (Prawiroharjo et al., 2019). Temuan ini tentu dapat menjadi masukan bagi penelitian selanjutnya untuk menggambarkan bagaimana variabel jenis kelamin dapat memberikan kontribusi bagi tinggi rendahnya perilaku cybersex dan dimungkinkan untuk menjadi moderator hubungan antara variabel-variabel yang mempengaruhi cybersex. 


\section{KESIMPULAN}

Penelitian ini menguatkan kembali temuan-temuan sebelumnya bahwa kontrol diri memiliki hubungan negatif dengan perilaku amoral seperti cybersex. Individu yang mampu mengontrol diri dalam penggunaan internet dianggap mampu terhindar dari paparan pornografi yang tergambar dari perilaku cybersex. Namun demikian interaksi remaja pada penggunaan internet memiliki sifat yang berkelanjutan dan terus menerus, sehingga kontrol diri bisa saja menurun dan akan berdampak pada perilaku cybersex. Adanya perbedaan laki-laki dan perempuan dalam perilaku cybersex juga menggambarkan temuan-temuan sebelumnya, meskipu secara keseluruhan temuan ini masih inkonsiten dan perlu di teliti lebih lanjut pada penelitian selanjutnya.

\section{DAFTAR PUSTAKA}

Anggreiny, N., \& Sarry, S. M. (2018). Kontrol Sosial Pada Remaja Yang Mengakses Cybersex. Jurnal RAP (Riset Aktual Psikologi Universitas Negeri Padang), 9(2), 160. https://doi.org/10.24036/rapun.v9i2.102212

APJII [Asosiasi Penyedia Jasa Internet Indonesia]. (2018a). Laporan Survei : Penetrasi \& Profil Perilaku Pengguna Internet Indonesia. APJII. Retrieved from www.apjii.or.id

APJII [Asosiasi Penyedia Jasa Internet Indonesia]. (2018b). Survei APJII: Penetrasi Internet di Indonesia Capai 143 Juta Jiwa. Buletin APJII, Edisi-22(Maret), 1-7.

APJII [Asosiasi Penyedia Jasa Internet Indonesia]. (2019). Laporan Survei : Penetrasi \& Profil Perilaku Pengguna Interneet Indonesia. Buletin APJII, Edisi 40(Mei), 1-6. Retrieved from https://apjii.or.id/survei

Ballester-Arnal, R., Giménez-García, C., Gil-Llario, M. D., \& Castro-Calvo, J. (2016). Cybersex in the "net generation": Online sexual activities among Spanish adolescents. Computers in Human Behavior, 57, 261-266. https://doi.org/10.1016/j.chb.2015.12.036

Cooper, A., Delmonico, D. L., \& Burg, R. (2000). Cybersex users, abusers, and compulsives: New findings and implications. Sexual Addiction and Compulsivity, 7(1-2), 5-29. https://doi.org/10.1080/10720160008400205

Daneback, K., Cooper, A., \& Månsson, S. A. (2005). An internet study of cybersex participants. Archives of Sexual Behavior, 34(3), 321-328. https://doi.org/10.1007/s10508-005-3120-z

Dewangga, L. K., \& Rahayu, M. S. (2015). Hubungan antara kontrol diri dengan Cybersexual Addiction pada siswa SMP di Orange-Net Bandung. Prosiding Psikologi, ISSN : 24606448, 137-143.

Ghufron, M., \& Risnawita, R. (2012). Teori-teori Psikologi (Cetakan ke). Yogyakarta: ArRuzz.

KPAI. (2014). KPAI : 90 \% Anak Terpapar Pornografi Internet saat Usia 11 tahun. Retrieved from https://www.kpai.go.id/berita/kpai-90-persen-anak-terpapar-pornografi-internetsaat-usai-11-tahun

Lestari, A. I., \& Hartosujono, H. (2017). Hubungan Kontrol Diri Dengan Perilaku Cybersex 
Remaja Pada Pengguna Warung Internet Di Glagah Sari Yogyakarta. Jurnal Spirits, 4(2), 65. https://doi.org/10.30738/spirits.v4i2.1116

Phelan, J., \& Burnham, T. C. (2000). Mean Genes : From Sex To Money To Food: Taming Our Primal Instincts. USA: Perseus Publishing.

Prawiroharjo, P., Ellydar, H., Pratama, P., Edison, R. E., Suaidy, S. E. I., Amani, N. Z., \& Carissima, D. (2019). Impaired Recent Verbal Memory in Pornography-Addicted Juvenile Subjects. Neurology Research International, 2019. https://doi.org/10.1155/2019/2351638

Rahman, A. A., \& Permadi, R. (2013). Pengaruh Identitas Keberagamaan Dan Kejijikan Moral Terhadap Perilaku Cybersex. Psikologika: Jurnal Pemikiran Dan Penelitian Psikologi, 18(1), 5-13. https://doi.org/10.20885/psikologika.vol18.iss1.art2

Tangney, J. P., Baumeister, R. F., \& Boone, A. L. (2004). High self-control predicts good adjustment, less pathology, better grades, and interpersonal success. Journal of Personality, 2(April 2004), 54.

Utari, Syarifah, \& Lubis, N. L. (2012). Hubungan media elektronik dengan perilaku siswa tentang seks pra-nikah di SMK Muhammadiyah 2 Kota Pematangsiantar tahun 2012. Kebijakan, Promosi Kesehatan Dan Biostatistika, 1(1), 46-48. https://doi.org/10.4172/2161-0525.S4-006

Weinstein, A. M., Zolek, R., Babkin, A., Cohen, K., \& Lejoyeux, M. (2015). Factors predicting cybersex use and difficulties in forming intimate relationships among male and female users of cybersex, 6(April), 1-8. https://doi.org/10.3389/fpsyt.2015.00054 